\title{
Modeling nitrogen cycling in a coastal fresh water sediment
}

\author{
Richard W. Canavan · Anniet M. Laverman • \\ Caroline P. Slomp
}

(C) Springer Science+Business Media B.V. 2007

\begin{abstract}
Increased nitrogen (N) loading to coastal marine and freshwater systems is occurring worldwide as a result of human activities. Diagenetic processes in sediments can change the $\mathrm{N}$ availability in these systems, by supporting removal through denitrification and burial of organic $\mathrm{N}\left(\mathrm{N}_{\text {org }}\right)$ or by enhancing $\mathrm{N}$ recycling. In this study, we use a reactive transport model (RTM) to examine $\mathrm{N}$ transformations in a coastal fresh water sediment and quantify $\mathrm{N}$ removal rates. We also assess the response of the sediment $\mathrm{N}$ cycle to environmental changes that may result from increased salinity which is planned to occur at the site as a result of an estuarine restoration project. Field results show that much of the $\mathrm{N}_{\text {org }}$ deposited on the sediment is currently remineralized to ammonium. A
\end{abstract}

Guest editors: R. D. Gulati, E. Lammens, N. De Pauw \& E. Van Donk

Shallow lakes in a changing world

R. W. Canavan $(\bowtie) \cdot$ A. M. Laverman .

C. P. Slomp

Department of Earth Sciences - Geochemistry,

Faculty of Geosciences, Utrecht University, 80.021,

3508 TA Utrecht, The Netherlands

e-mail: R.Canavan@geo.uu.nl

Present Address:

A. M. Laverman

UMR 7619 Sisyphe, Université Pierre et Marie Curie,

4 Place Jussieu, 75252 Paris, France rapid removal of nitrate is observed in the sediment pore water, with the resulting nitrate reduction rate estimated to be $130 \mu \mathrm{mol}$ $\mathrm{N} \mathrm{cm}^{-2} \mathrm{yr}^{-1}$. A model sensitivity study was conducted altering the distribution of nitrate reduction between dissimilatory nitrate reduction to ammonium (DNRA) and denitrification. These results show a $40 \%$ decline in sediment $\mathrm{N}$ removal as $\mathrm{NO}_{3}^{-}$reduction shifts from denitrification to DNRA. This decreased $\mathrm{N}$ removal leads to a shift in sediment-water exchange flux of dissolved inorganic nitrogen (DIN) from near zero with denitrification to $133 \mu \mathrm{mol}$ $\mathrm{N} \mathrm{cm}{ }^{-2} \mathrm{yr}^{-1}$ if DNRA is the dominant pathway. The response to salinization includes a shortterm release of adsorbed ammonium. Additional changes expected to result from the estuarine restoration include: lower $\mathrm{NO}_{3}^{-}$ concentrations and greater $\mathrm{SO}_{4}^{2-}$ concentrations in the bottom water, decreased nitrification rates, and increased sediment mixing. The effect of these changes on net DIN flux and $\mathrm{N}$ removal vary based on the distribution of DNRA versus denitrification, illustrating the need for a better understanding of factors controlling this competition.

Keywords denitrification - dissimilatory nitrate reduction to ammonium (DNRA) . ammonium adsorption - diagenetic model . sediment-water exchange $\cdot$ salinity 


\section{Introduction}

Nitrogen (N) inputs to freshwater and near shore marine systems have increased strongly due to human activities, leading to eutrophication (Cloern, 2001; de Jonge et al., 2002). A significant fraction of this excess $\mathrm{N}$ may be removed in the sediment through denitrification or burial of organic $\mathrm{N}\left(\mathrm{N}_{\text {org }}\right)$. This nitrogen removal has been shown to correlate to $\mathrm{N}$ input loads and discharge rates of water (Windolf et al., 1996; Saunders \& Kalff, 2001). Aquatic systems with high discharge rates have lower removal rates as sediment-water interactions are limited.

Removal through denitrification may also be limited by competition with an alternative sediment pathway, dissimilatory nitrate reduction to ammonium (DNRA). DNRA has been found to be a significant pathway of nitrate reduction in a variety of sediments and saturated soils (Gilbert et al., 1997; Ogilvie et al., 1997; Revsbech et al., 2005). It is thought that an abundance of organic carbon relative to $\mathrm{NO}_{3}^{-}$favors DNRA over denitrification, but little is known about the competition between the organisms responsible for the two pathways (Megonigal et al., 2003). The difference between these two pathways is significant for water quality as denitrification produces a form of gaseous $\mathrm{N}$ that is generally unavailable to primary producers, while the $\mathrm{NH}_{4}^{+}$ produced through DNRA is readily bioavailable (Fig. 1). In addition to diffusion from the overlying water, nitrification of $\mathrm{NH}_{4}^{+}$in the oxic surface sediment can also be an important source of $\mathrm{NO}_{3}^{-}$ for reduction (Seitzinger, 1988).

Ammonium can be retained in sediment due to adsorption at cation exchange sites, which are present on the surface of organic matter and clay minerals (Berner, 1980). Salinization of fresh water sediments can cause the desorption of $\mathrm{NH}_{4}^{+}$from cation exchange sites as a result of competition with $\mathrm{Na}^{+}$ions (Seitzinger et al., 1991). Lower nitrification rates (Gardner et al., 1991; Rysgaard et al., 1999), increased $\mathrm{NO}_{2}^{-}$ production, and increased rates of organic matter mineralization (Nyvang, 2003) have also been associated with increased salinity. Salinization of fresh waters, and the associated changes in $\mathrm{N}$ cycling, may occur in the coastal zone due to

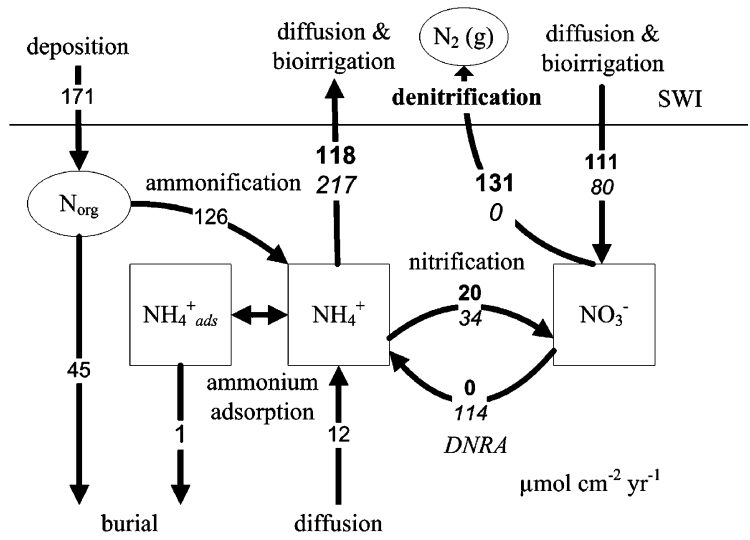

Fig. 1 A schematic diagram of the sedimentary $\mathrm{N}$ cycle with both reaction and transport processes labeled. Model derived values of rates and fluxes for the upper $30 \mathrm{~cm}$ of sediment are presented on the arrows in $\mu \mathrm{mol} \mathrm{N} \mathrm{cm}{ }^{-2} \mathrm{yr}^{-1}$. Results of two steady-state simulations are shown, in one simulation all nitrate reduction occurs via denitrification (bold), in the other via DNRA (italics). The influx of organic matter and mineralization rates were kept constant

rising sea level, dam construction, and ground water withdrawal.

Our study site is currently a freshwater lake that will become brackish from 2008 onwards as a result of an ecological restoration project. In this study we adapt a previously developed reactive transport model (Canavan et al., 2006), to examine the response of the sediment $\mathrm{N}$-cycle to changes that may result from salinization of this fresh water lake. Possible changes in site conditions are represented by changing parameters in steady-state and transient simulations. To allow for a more detailed model representation of the sediment $\mathrm{N}$ processes the existing model was adapted to include DNRA, in addition to denitrification, as experimental results suggest a possible role for DNRA at the site (Laverman et al., 2006). In this model sensitivity study, we specifically focus on the consequences for net sediment dissolved inorganic nitrogen (DIN) efflux rates.

\section{Methods}

Study Site

Haringvliet Lake (The Netherlands) is a eutrophic freshwater lake in the southwestern Netherlands. The lake was created as a result of 
damming of the mouth of a tidal estuary in 1970. Prior to dam construction, the Haringvliet was an outlet of the Meuse-Rhine River system to the North Sea. The closure of the Haringvliet caused physical and chemical changes in the water body, including the disappearance of the salinity gradient and the accumulation of river derived suspended matter (Smit et al., 1997). The lake is relatively shallow; the water depth at the sample site was $7.5 \mathrm{~m}$. The lake retains some fluvial characteristics, such as high flow rates. The residence time of water in Haringvliet Lake is typically on the order of several days (Smit et al., 1997), however periods of increased residence time occur when river levels are low and discharge through the dam is stopped. Thermal stratification and bottom water anoxia are not observed. A partial restoration of estuarine conditions in Haringvliet Lake is proposed to increase the diversity and availability of estuarine habitat in the area (Anonymous, 1998). Restoration would be achieved by changing the opening and closing of gates in the dam that separates the lake from the North Sea. Our sample location was located near the dam in an area that would be affected by the restoration $(51.50 .080 \mathrm{~N}, 04.04 .328$ E). The sediment at the site was fine-grained and highly porous. A previous study at this site indicates organic matter mineralization rates on the order of $764 \mu \mathrm{mol} \mathrm{cm} \mathrm{cm}^{-2}$ where oxic degradation (55\%), nitrate reduction (21\%) and sulfate reduction (17\%) are the important degradation pathways (Canavan et al., 2006).

Sample collection and analysis

Field sampling was carried out in November 2001, September 2002, and April 2003. These sampling times are referred to in the text as fall, latesummer, and spring, respectively. Sediment was collected using a cylindrical box corer (31 cm i.d.) deployed from RV Navicula. Sub-cores were taken with polycarbonate tubes $(10 \mathrm{~cm}$ i.d.) and immediately sectioned in a $\mathrm{N}_{2}$ purged glove box on board the ship. Sediment was centrifuged at $2500 \mathrm{~g}$ for 10 to 30 minutes in polyethylene tubes to collect pore water. After centrifugation, tubes were transferred to a $\mathrm{N}_{2}$ purged glove box, and the pore water was filtered through 0.2 or $0.45 \mu \mathrm{m}$ pore size filters. Pore water was then sub-divided and preserved for the different analyses. Subsamples for $\mathrm{NO}_{3}^{-}$and $\mathrm{NH}_{4}^{+}$were stored frozen until analysis at the laboratory and were determined colorimetrically on a nutrient auto-analyzer (Bran and Luebbe). Dissolved oxygen microprofiles were determined on-board the sampling ship with a Clark-type oxygen sensor as described in Canavan et al. (2006). Sediment C and $\mathrm{N}$ contents were determined on freeze dried sediments using a Carlo Erba $\mathrm{CN}$ analyzer and a LECO CS analyzer.

\section{Model development}

RTM calculations of 1-D sediment profiles were carried out with the Biogeochemical Reaction Network Simulator (BRNS; Aguilera et al., 2005; Jourabchi et al., 2005). The development and calibration of the model, which includes a reaction network of 24 chemical species and 32 reactions, is presented in detail in Canavan et al. (2006). The current study focuses solely on the sediment $\mathrm{N}$-cycle, therefore the model description and results are limited to $\mathrm{N}$ transformation processes. The RTM includes $6 \mathrm{~N}$-species: $\mathrm{NH}_{4}^{+}$, $\mathrm{NO}_{3}^{-}$, adsorbed $\mathrm{NH}_{4}^{+}\left(\mathrm{NH}_{4}^{+}\right.$ads $)$, and three pools of $\mathrm{N}_{\text {org }}$ (Table 1), which are linked to the organic carbon pools through $\mathrm{C}: \mathrm{N}$ ratios. The different organic matter pools are abbreviated as OM1, a highly reactive pool, OM2, a less reactive pool, and OM3, a refractory (non-reactive) pool (Westrich \& Berner, 1984). Upper boundary conditions for the $\mathrm{N}$-species are given in Table 1. All lower boundaries are set to no-flux conditions,

Table 1 Model nitrogen species and upper boundary conditions

\begin{tabular}{lclcl}
\hline solute & $\mu \mathrm{M}$ & solid & $\left(\mu \mathrm{mol} \mathrm{cm} \mathrm{yr}^{-1}\right)$ & $\mathrm{CN}$ ratio \\
\hline $\mathrm{NO}_{3}^{-}$ & 154 & $\mathrm{~N}_{\text {org-OM1 }}$-O & 113 & 5.6 \\
$\mathrm{NH}_{4}^{+}$ & 14.5 & $\mathrm{~N}_{\text {org-OM2 }}$ & 32 & 10 \\
& & $\mathrm{~N}_{\text {org-OM3 }}$ & 27 & 20 \\
& & $\mathrm{NH}_{4}^{+}$ads & 0 & - \\
\hline
\end{tabular}

$\mathrm{NO}_{3}^{-}$and $\mathrm{NH}_{4}^{+}$upper boundary concentrations are mean values of overlying water from the three sampling events. Input fluxes of $\mathrm{N}_{\text {org }}$ were calculated from the input fluxes for the three organic matter pools and $\mathrm{CN}$ ratios that were defined for those pools 
where the lower boundary of the simulation was $100 \mathrm{~cm}$.

The decomposition of organic matter, which is modeled as a first order process defined by a rate constant $\mathrm{kOM}\left(\mathrm{yr}^{-1}\right)$, results in the mineralization of $\mathrm{N}_{\text {org }}$ (Table 2). Organic matter mineralization occurs with a series of terminal electron acceptors: $\mathrm{O}_{2}, \mathrm{NO}_{3}^{-}$, Mn-oxides, Fe-oxides, $\mathrm{SO}_{4}^{2-}$, and organic carbon. The distribution of the total organic matter decomposition rate over the different terminal electron acceptor pathways follows the approach of Van Cappellen \& Wang, (1996). The model reaction network, which initially included only denitrification, was adapted to include both nitrate reduction pathways. The DNRA reactions were added to the reaction network (Table 2) and a term fDNRA was included to distribute the total nitrate reduction between the two pathways. This $f$ DNRA term is set empirically and equals the fraction of total nitrate reduction occurring via DNRA. The fraction of total nitrate reduction occurring by denitrification is defined as 1-fDNRA. Because this study uses the boundary conditions calibrated in Canavan et al. (2006) the initial value of $f$ DNRA is set to zero. Sensitivity of sediment processes to changes in the distribution of nitrate reduction pathways is examined by varying the fDNRA term. With the exception of Kelly-Gerreyn et al. (2001), existing sediment diagenetic models ignore DNRA and assume all nitrate reduction to occur via denitrification.

The oxidation of $\mathrm{NH}_{4}^{+}$with $\mathrm{O}_{2}$ (nitrification) is described with a bimolecular rate law (Table 2; Van Cappellen \& Wang, 1996). Adsorption of $\mathrm{NH}_{4}^{+}$to cation exchange sites is represented by a linear equilibrium isotherm, with a constant adsorption coefficient, $\mathrm{K}_{\mathrm{N}}$ (Berner, 1980; Van Cappellen \& Wang, 1996). $\mathrm{K}_{\mathrm{N}}$ is a dimensionless adsorption coefficient:

$K_{N}=\left(\frac{1-\phi}{\phi}\right) \rho K^{*}$

where $\phi$ is porosity (vol. \% porewater), $\rho$ is sediment density $\left(\mathrm{g} \mathrm{cm}^{-3}\right)$, and $\mathrm{K}^{*}\left(\mathrm{~cm}^{3} \mathrm{~g} \mathrm{dw}^{-1}\right)$ is the ratio of $\mathrm{NH}_{4 \text { ads }}^{+}\left(\mu \mathrm{mol} \mathrm{g} \mathrm{dw}{ }^{-1}\right)$ to $\mathrm{NH}_{4}^{+}(\mathrm{mM})$. The concentration of $\mathrm{NH}_{4 \text { ads }}^{+}$is estimated to be

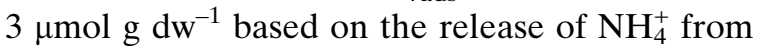
sediment flow through reactors exposed to increased salinity (Laverman, unpublished results). Using this estimate and the corresponding pore water $\mathrm{NH}_{4}^{+}$concentration of $0.077 \mathrm{mM}$, gives a value of $39\left(\mathrm{~cm}^{3} \mathrm{~g} \mathrm{dw}^{-1}\right)$ for $\mathrm{K}^{*}$ and of 10 for $\mathrm{K}_{\mathrm{N}}$. Both values fall within the range reported for fresh water sediments by Seitzinger et al. (1991).

The model includes transport of solutes by molecular diffusion, bioirrigation, bioturbation, and advection (burial). Transport of solids occurs by bioturbation and advection. Molecular

Table 2 Nitrogen containing reactions in the model

\begin{tabular}{|c|c|}
\hline Reactions & $\begin{array}{l}\text { Kinetic or equilibrium } \\
\text { formulation }\end{array}$ \\
\hline $\begin{array}{l}\text { Ammonification }{ }^{\mathrm{a}, \mathrm{b}} \\
{\left[\left(\mathrm{CH}_{2} \mathrm{O}\right)_{\mathrm{y}}\left(\boldsymbol{N H}_{3}\right)_{\mathrm{z}}\right]+\mathrm{yTEAox} \rightarrow \mathrm{zNH}_{4}^{+}++\mathrm{yCO}_{2}+\mathrm{yH}_{2} \mathrm{O}+\mathrm{yTEA}_{\mathrm{red}}} \\
\text { Denitrification }\end{array}$ & $\mathrm{k}_{\mathrm{OM}}[\mathrm{OM}] f_{\mathrm{TEA}}$ \\
\hline $\begin{array}{l}{\left[\left(\mathrm{CH}_{2} \mathrm{O}\right)_{\mathrm{y}}\left(\boldsymbol{N H}_{3}\right)_{\mathrm{z}}\right]+0.8 \mathrm{y} \boldsymbol{N O}_{\mathbf{3}}^{-} \rightarrow \mathrm{zNH}_{\mathbf{4}}^{+}+0.4 \mathrm{y} \boldsymbol{N}_{\mathbf{2}}+(0.2 \mathrm{y}-\mathrm{z}) \mathrm{CO}_{2}} \\
\quad+(0.8 \mathrm{y}+\mathrm{z}) \mathrm{HCO}_{3}^{-}+(0.6 \mathrm{y}-\mathrm{z}) \mathrm{H}_{2} \mathrm{O}\end{array}$ & $\mathrm{k}_{\mathrm{OM}}[\mathrm{OM}] f_{\mathrm{NO} 3}(1-f \mathrm{DRNA})$ \\
\hline $\begin{array}{l}\text { DNRA } \\
{\left[\left(\mathrm{CH}_{2} \mathrm{O}\right)_{\mathrm{y}}\left(\boldsymbol{N H}_{3}\right)_{\mathrm{z}}\right]+0.5 \mathrm{y} \boldsymbol{N O}_{\mathbf{3}}^{-}+\mathrm{zCO}_{2}+(0.5 \mathrm{y}+\mathrm{z}) \mathrm{H}_{2} \mathrm{O} \rightarrow(0.5 \mathrm{y}+\mathrm{z}) \boldsymbol{N H}_{4}^{+}+(\mathrm{y}+\mathrm{z}) \mathrm{HCO}_{3}^{-}} \\
\text {Nitrification }\end{array}$ & $\mathrm{k}_{\mathrm{OM}}[\mathrm{OM}] f_{\mathrm{NO} 3} f \mathrm{DRNA}$ \\
\hline $\begin{array}{c}\mathbf{N H}_{4}^{+}+2 \mathrm{O}_{2}+2 \mathrm{HCO}_{3}^{-} \\
\text {Ammonium adsorption }\end{array}$ & $\mathrm{k}_{\mathrm{NH} 4 \mathrm{OX}}\left[\mathrm{NH}_{4}^{+}\right]\left[\mathrm{O}_{2}\right]$ \\
\hline $\mathbf{N H}_{4}^{+}$ads $\leftrightarrow \boldsymbol{N H}_{4}^{+}\left(\mathrm{K}_{\mathrm{N}} \varphi / \rho(1-\varphi)\right)$ & $\mathrm{K}_{\mathrm{N}}\left[\mathrm{NH}_{4}^{+}\right]$ \\
\hline
\end{tabular}

${ }^{\text {a }}$ Organic matter is represented by the formula $\left[\left(\mathrm{CH}_{2} \mathrm{O}\right)_{\mathrm{y}}\left(\mathrm{NH}_{3}\right)_{\mathrm{z}}\right]$ where $\mathrm{y} / \mathrm{z}$ is the $\mathrm{C} / \mathrm{N}$ ratio. ${ }^{\mathrm{b}} \mathrm{A}$ generalized mineralization reaction is depicted for ammonification where $\mathrm{TEA}_{\mathrm{ox}}$ and $\mathrm{TEA}_{\text {red }}$ represent the oxidized and reduced terminal electron acceptor. The term $f_{\text {TEA }}$ defines the fraction of the total carbon mineralization by each TEA pathway (Van Cappellen and Wang, 1996), for example $f_{\mathrm{NO} 3}$ represents the nitrate reduction pathways. ${ }^{\mathrm{c}} \mathrm{K}_{\mathrm{N}}$ is the dimensionless adsorption coefficient as defined in eq. 1 
diffusion and the associated tortuosity and temperature effects are included as described in Van Cappellen \& Wang (1996). Bioirrigation is represented as a non-local exchange with the surface water of which the intensity is controlled by the coefficient, $\alpha$ (Boudreau, 1984); and bioturbation is parameterized using an additional diffusion term, $\mathrm{D}_{\mathrm{b}}$ (Berner, 1980). The advective velocity of solids and solutes is determined from the sediment accumulation rate, $\omega\left(\mathrm{cm} \mathrm{yr}^{-1}\right)$ and porosity $(\varphi)$ as described by Berner (1980). Table 3 includes a list of parameter values used in the model including the depth distributions of $\alpha, \mathrm{D}_{\mathrm{b}}$, and $\varphi$.

\section{Results}

The oxygen penetration depth was between 0.3 to $0.6 \mathrm{~cm}$ in the sediment (Fig 2). Nitrate concentrations in the overlying water ranged from $120-180 \mu \mathrm{M}$, while $\mathrm{NO}_{3}^{-}$in pore water from the $0-0.5 \mathrm{~cm}$ layer was always below $5 \mu \mathrm{M}$. The relatively coarse scale of the pore water sampling $(0.5 \mathrm{~cm}$ sections in the upper $2 \mathrm{~cm})$ and the rapid reduction of nitrate in the samples, limits the resolution of measured pore water $\mathrm{NO}_{3}^{-}$. Typically the $\mathrm{NO}_{3}^{-}$penetration should extend below that of $\mathrm{O}_{2}$ (Stief et al., 2003). The resolution of the $\mathrm{O}_{2}$ profiles is improved by the use of the microelectrode. Pore water $\mathrm{NH}_{4}^{+}$concentrations increased with depth, as a result of ammonification. Seasonal differences in $\mathrm{NH}_{4}^{+}$were observed in the upper $17 \mathrm{~cm}$ with highest concentrations in spring and lowest in fall, where high $\mathrm{NH}_{4}^{+}$corresponded with shallower $\mathrm{O}_{2}$ penetration. The $\mathrm{NH}_{4}^{+}$ profiles exhibit evidence of bioirrigation in the upper $17 \mathrm{~cm}$ with somewhat homogeneous concentrations, while below this depth upward diffusion is evident. Sediment $\mathrm{N}_{\text {org }}$ concentrations decline with depth due to organic matter decomposition.

\section{Discussion}

The model derived profiles of $\mathrm{O}_{2}, \mathrm{NO}_{3}^{-}, \mathrm{NH}_{4}^{+}$, and $\mathrm{N}_{\text {org }}$ capture the vertical trends observed in the measured values (Fig. 2). The modeled $\mathrm{NH}_{4}^{+}$ concentrations are greater when fDNRA is 1 .

Table 3 Initial parameter values and distributions

\begin{tabular}{|c|c|c|c|}
\hline Parameter & Value & Unit & Description \\
\hline $\mathrm{k}_{\mathrm{OM} 1}$ & 25 & $\mathrm{yr}^{-1}$ & degradation rate constant OM1 \\
\hline $\mathrm{k}_{\mathrm{OM} 2}$ & 0.01 & $\mathrm{yr}^{-1}$ & degradation rate constant $\mathrm{OM} 2$ \\
\hline $\mathrm{k}_{\mathrm{OM} 3}$ & 0 & $\mathrm{yr}^{-1}$ & degradation rate constant OM3 \\
\hline $\mathrm{K}_{\mathrm{N}}$ & 10 & - & $\mathrm{NH}_{4}^{+}$adsorption coefficient (eq. 1) \\
\hline$f \mathrm{DNRA}$ & 0 & - & fraction of nitrate reduction occurring as DNRA \\
\hline $\mathrm{k}_{\mathrm{NH} 4 \mathrm{OX}}$ & 20 & $\mu \mathrm{M}^{-1} \mathrm{yr}^{-1}$ & nitrification rate constant \\
\hline$\omega$ & 1.0 & 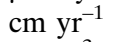 & sediment accumulation rate \\
\hline$\rho$ & 2.1 & $\mathrm{~g} \mathrm{~cm}^{-3}$ & sediment density \\
\hline$\alpha_{0}$ & 10 & $\mathrm{yr}^{-1}$ & bioirrigation coefficient at surface \\
\hline $\mathrm{D}_{\mathrm{b} 0}$ & 5 & $\mathrm{~cm}^{2} \mathrm{yr}^{-1}$ & bioturbation coefficient at surface \\
\hline$\lambda$ & 2.5 & $\mathrm{~cm}^{-1}$ & $\mathrm{D}_{\mathrm{b}}$ depth attenuation coefficient \\
\hline$\varphi_{\mathrm{o}}$ & 0.89 & $\mathrm{~cm}^{3} \mathrm{~cm}^{-3}$ & porosity at surface \\
\hline$\varphi_{\infty}$ & 0.79 & $\mathrm{~cm}^{3} \mathrm{~cm}^{-3}$ & porosity at depth \\
\hline$\tau$ & 0.2 & $\mathrm{~cm}^{-1}$ & $\varphi$ depth attenuation coefficient \\
\hline $\mathrm{x}$ & $0-30$ & $\mathrm{~cm}$ & sediment depth \\
\hline \multicolumn{2}{|c|}{ Depth distributions } & \multicolumn{2}{|c|}{ Description } \\
\hline \multicolumn{2}{|l|}{$\alpha=\{$} & \multicolumn{2}{|c|}{ Distribution of bioirrigation coefficient $\alpha$} \\
\hline \multicolumn{2}{|c|}{$D_{b}=D_{b 0} e^{-\left(\frac{x}{\lambda}\right)}$} & \multicolumn{2}{|c|}{ Distribution of bioturbation coefficient $\mathrm{Db}$} \\
\hline \multicolumn{2}{|c|}{$\varphi(\mathrm{x})=\varphi_{\infty}+\left(\varphi_{\mathrm{o}}-\varphi_{\infty}\right) e^{-(\tau \mathrm{x})}$} & \multicolumn{2}{|c|}{ porosity distribution } \\
\hline
\end{tabular}



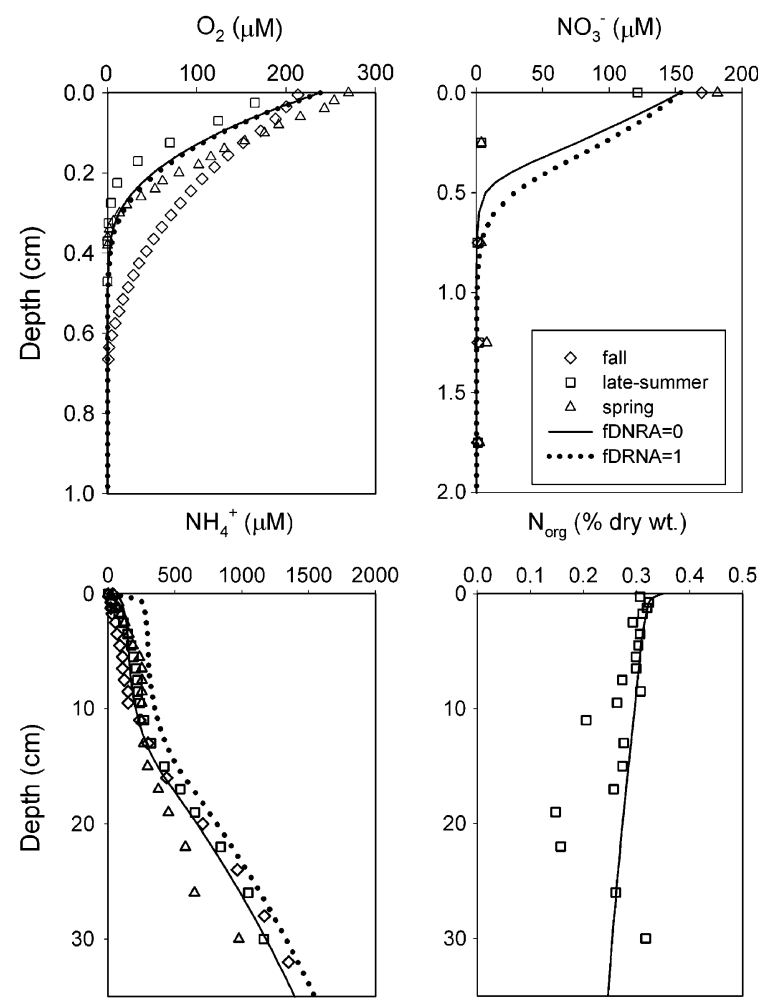

Fig. 2 Sediment pore water $\mathrm{O}_{2}, \mathrm{NO}_{3}^{-}$, and $\mathrm{NH}_{4}^{+}$concentrations and sediment organic nitrogen $\left(\mathrm{N}_{\text {org }}\right)$ concentrations from fall $(\diamond)$,late-summer $(\square)$, and spring $(\Delta)$. Steady-state model derived profiles for porewater species are plotted for $f \mathrm{DNRA}=0$ (solid line) and for $f$ DNRA $=1$ (dotted line). The modeled $\mathbf{N}_{\text {org }}$ profile is not sensitive to changes in fDNRA which is depicted with a solid line

The model was calibrated for the condition $f \mathrm{DRNA}=0$ (Canavan et al, 2006). It is not possible to estimate a possible value of $f \mathrm{DNRA}$ directly from the $\mathrm{NH}_{4}^{+}$profiles given the uncertainty in the input fluxes of organic matter. Model-derived rates of transport and reaction in the sediment are presented in the schematic representation of $\mathrm{N}$-cycling (Fig. 1) including results of two examples where all nitrate reduction occurs either by denitrification (in bold) or DNRA (in italics). The decomposition of organic matter releases $73 \%$ of the deposited $\mathrm{N}_{\text {org }}$ as $\mathrm{NH}_{4}^{+}$ in the upper $30 \mathrm{~cm}$ of sediment. Much of the remaining $\mathrm{N}_{\text {org }}$ is buried in the sediment, however, decomposition does continue deeper in the sediment resulting in the upward diffusion of $\mathrm{NH}_{4}^{+}$in the pore water. The major part of the
$\mathrm{NH}_{4}^{+}$generated by ammonification is transported to the overlying water, while approximately $15-26 \%$ is oxidized to $\mathrm{NO}_{3}^{-}$(nitrification). Limitation of nitrification in the sediment may be due to the shallow $\mathrm{O}_{2}$ penetration depth (Fig. 2), and competition from other processes such as oxic organic matter decomposition, and the oxidation of sulfides and methane (Canavan et al., 2006). Low rates of nitrification have been observed in coastal sediment with significant DNRA activity (Gilbert et al., 1997, shellfish farm site; An \& Gardner, 2002; Magalhães et al., 2005, muddy sediment site). Conditions favoring DNRA over denitrification, such as highly reduced sediments, and low $\mathrm{NO}_{3}^{-}$concentrations relative to organic substrate availability, may also contribute to low nitrification rates (Megonigal et al., 2003).

\section{Role of Denitrification versus DNRA}

Experimental results from flow through reactor (FTR) experiments show that potential rates of denitrification were approximately $50 \%$ less than those of $\mathrm{NO}_{3}^{-}$reduction at our site (Laverman et al., 2006). Conditions in the FTR experiments favor denitrification over DNRA when compared to the in-situ conditions as $\mathrm{NO}_{3}^{-}$concentrations in the FTRs were greater (Sørensen, 1987). Initial experimental evidence from the site (Laverman et al. 2006; unpublished results of $\mathrm{N}_{2} \mathrm{O}$ microprofiling) suggests that a significant portion of the nitrate reduction in the sediment occurs by processes other than denitrification. To examine how the competition between DNRA and denitrification affects the $\mathrm{N}$-cycle at our site we conducted several steady state simulations while varying $f$ DNRA from 0 (all denitrification) to 1 (all DNRA).

The removal of $\mathrm{N}$ entering the sediment $\left(\mathrm{NO}_{3}^{-}\right.$ influx and $\mathrm{N}_{\text {org }}$ deposition) ranges from $63 \%$ to $18 \%$, with maximum removal occurring at $f$ DNRA $=0$ (Fig. 3a). The decreased $\mathrm{N}$ removal with increasing prevalence of DNRA leads to a shift from a situation where sediment is essentially neutral with respect to DIN efflux to one there the sediment is a net source with an efflux rate of $133 \mu \mathrm{mol} \mathrm{cm} \mathrm{cm}^{-2}$. The $\mathrm{NH}_{4}^{+}$efflux ranged from 115 to $213 \mu \mathrm{mol} \mathrm{cm}{ }^{-2} \mathrm{yr}^{-1}$. Such high $\mathrm{NH}_{4}^{+}$efflux rates have been found in other 

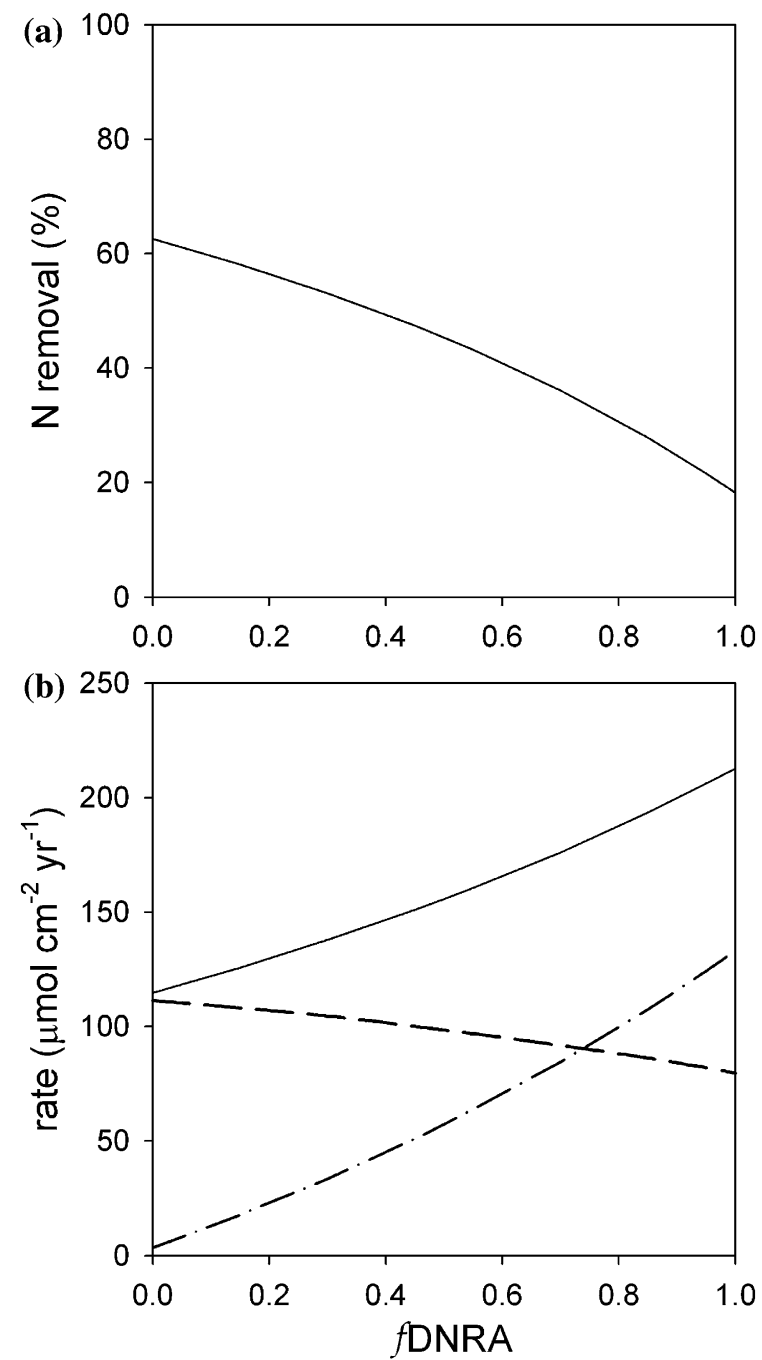

Fig. 3 The $\mathrm{N}$ removal as a percentage of the total $\mathrm{N}$ influx to the sediment for steady-state simulations where fDNRA was varied from $0-1$ (a). $\mathrm{N}$ removal is calculated from denitrification and burial (at $30 \mathrm{~cm}$ ) and sediment input is $\mathrm{N}_{\text {org }}$ deposition and $\mathrm{NO}_{3}^{-}$influx. The rates of sediment ammonium efflux (solid line), nitrate influx (dashed line), and net DIN efflux (dash dot line) versus $f$ DNRA are presented in plot (b)

freshwater sediments $\left(65-307 \mu \mathrm{mol} \mathrm{cm} \mathrm{cm}^{-2} \mathrm{yr}^{-1}\right.$; Gardner et al., 2001). However, in sediments with a greater rate of coupled nitrification-denitrification, the $\mathrm{NH}_{4}^{+}$efflux is typically lower as more $\mathrm{N}$ is released as $\mathrm{N}_{2}$ (Seitzinger, 1988). Nitrate influx decreased with increasing values of fDNRA (Fig. 3b), due to an accompanying increase in nitrification rate. In our simulations, much of the $\mathrm{NO}_{3}^{-}$reduced in the sediment is transported from the overlying water, while only $15-30 \%$ of reduced $\mathrm{NO}_{3}^{-}$is produced by nitrification (Fig. 1).

Ammonium adsorption response to salinization

The release of $\mathrm{NH}_{4 \text { ads }}^{+}$in response to increasing salinity was examined with a transient model simulation. Results from the steady-state simulation using the parameter values listed in Table 3 were used as the initial conditions in a simulation where the value of $K_{\mathrm{N}}$ was reduced from 10 to 1.3 based on an estimate for marine sediments (Mackin \& Aller, 1984). The response of the sediment is very rapid. Over the first day, the $\mathrm{NH}_{4}^{+}$efflux was approximately 2.5 times greater than was observed for the initial conditions, primarily driven by the diffusive efflux (Fig. 4). Ammonium released to the pore water at depth is transported to the overlying water via bioirrigation, which responds more slowly. Ammonium efflux declines to rates that are $15 \%$ greater than found for the initial conditions after a 6-month simulation period (not shown).

\section{Estuarine Restoration}

Restoration of the estuary will result in changes to the bottom water chemistry and sediment pore water. In addition to greater $\mathrm{Na}^{+}$and $\mathrm{Cl}^{-}$ concentrations, the coastal water adjacent to the

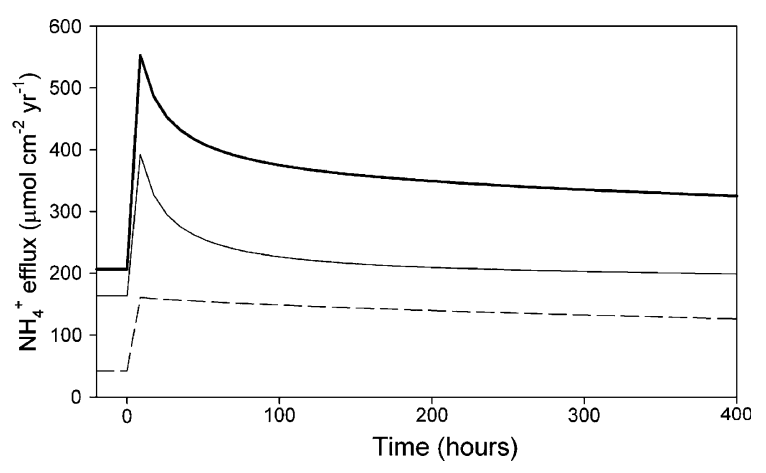

Fig. 4 Ammonium efflux from freshwater sediment subject to salinization. Results determined in a transient simulation where $\mathrm{K}_{\mathrm{N}}$ was initially 10 and reduced to 1.3 at the start of the simulation (time $=0$ ). Efflux by diffusion is the thin solid line, efflux via bioirrigation is the dashed line and the sum of the two processes is the thick solid line 
Table 4 Sediment DIN flux $\left(\mathrm{NH}_{4}^{+}\right.$efflux $-\mathrm{NO}_{3}^{-}$influx $)$and $\mathrm{N}$ removal (denitrification $+\mathrm{N}_{\text {org }}$ burial) from steady-state simulations made to approximate possible changes resulting from estuarine restoration. Simulations were made with the initial conditions of only denitrification $(f \mathrm{DNRA}=0)$ and where DNRA accounted for $95 \%$ of nitrate reduction $(f \mathrm{DNRA}=0.95)$. Additional simulations where the input flux of labile organic matter (OM1) was decreased are also presented

\begin{tabular}{|c|c|c|c|c|c|c|}
\hline \multirow[t]{3}{*}{ Parameter $^{\mathrm{a}}$} & \multirow[t]{3}{*}{ Initial value } & \multirow[t]{3}{*}{ New value } & \multicolumn{2}{|c|}{$f \mathrm{DNRA}=0$} & \multicolumn{2}{|c|}{$f \mathrm{DNRA}=0.95$} \\
\hline & & & DIN flux & $\mathrm{N}$ removal & DIN flux & $\mathrm{N}$ removal \\
\hline & & & \multicolumn{4}{|c|}{$\left(\mu \mathrm{mol} \mathrm{cm}{ }^{-2} \mathrm{yr}^{-1}\right)$} \\
\hline Initial conditions & - & 3 & 177 & 124 & 55 & \\
\hline $\mathrm{NO}_{3}^{-}(\mu \mathrm{M})$ & 154 & 90 & 39 & 141 & 126 & 53 \\
\hline $\mathrm{SO}_{4}^{2-}(\mathrm{mM})$ & 0.64 & 10 & 3 & 177 & 124 & 55 \\
\hline $\mathrm{O}_{2}(\mu \mathrm{M})$ & 238 & 120 & -42 & 222 & 121 & 57 \\
\hline $\mathrm{K}_{\mathrm{N}}$ & 10 & 1.3 & 7 & 177 & 129 & 55 \\
\hline $\mathrm{D}_{\mathrm{b} 0}\left(\mathrm{~cm}^{2} \mathrm{yr}^{-1}\right)$ & 5 & 25 & -2 & 178 & 110 & 55 \\
\hline $\mathrm{k}_{\mathrm{NH} 4 \mathrm{OX}}\left(\mu \mathrm{M}^{-1} \mathrm{yr}^{-1}\right)$ & 20 & 10 & 7 & 173 & 124 & 54 \\
\hline $\mathrm{kOM} 1 \& 2\left(\mathrm{yr}^{-1}\right)$ & $25,0.01$ & $50,0.02$ & 14 & 164 & 130 & 46 \\
\hline All of the above changes & & & 7 & 165 & 127 & 47 \\
\hline input flux OM1 $\left(\mu \mathrm{mol} \mathrm{cm}{ }^{-2} \mathrm{yr}^{-1}\right)$ & 630 & 420 & 6 & 177 & 90 & 52 \\
\hline
\end{tabular}

a see table 3 for a description of parameters

dam contains less $\mathrm{NO}_{3}^{-}$and more $\mathrm{SO}_{4}^{2-}$. Salinity stratification in the water column is expected and this could further affect the chemistry of the bottom water, for example, by resulting in lower oxygen concentrations. Additionally, changes in the microbial population and benthic fauna are expected, which will affect rates of reaction and transport in the sediment. To examine the sediment response to these possible changes, steady-state simulations were run where parameters were changed to represent the new conditions. Many of the salinity-related changes result in small changes to the net DIN flux (positive values are efflux to overlying water) and sediment $\mathrm{N}$ removal (Table 4). All simulations conducted with fDNRA equal to zero showed greater $\mathrm{N}$ removal rates than those with $f$ DNRA equal to 0.95 . When denitrification dominated, DIN flux was sensitive to $\mathrm{O}_{2}$ and $\mathrm{NO}_{3}^{-}$concentrations. Lower $\mathrm{O}_{2}$ concentration in the overlying water led to increased $\mathrm{NO}_{3}^{-}$influx as demand for other terminal electron acceptors increased, while lower $\mathrm{NO}_{3}^{-}$concentration in the overlying water limited its transport into the sediment. In the DRNA dominated simulations, net DIN efflux was lowered by decreasing the input flux of highly reactive organic matter (OM1) and by increasing the amount of bioturbative mixing $\left(D_{b 0}\right)$. Both of these processes reduce the rate of ammonification in the upper most part of the sediment, which in turn, lowers the diffusive efflux of $\mathrm{NH}_{4}^{+}$to the overlying water. The response of $\mathrm{N}$ removal to environmental changes is generally greater in the denitrification dominated sediment, since in the sediment where DNRA is most important, removal is controlled mainly by burial.

\section{Conclusions}

Competition between denitrification and DNRA has a significant impact on $\mathrm{N}$ removal in aquatic sediments as only denitrification removes $\mathrm{N}$ from the system. Salinization results in a rapid and transient release of adsorbed $\mathrm{NH}_{4}^{+}$. When DNRA is a key pathway at our site, changes in the chemistry of the overlying water and in reaction and transport parameters expected upon salinization do not significantly change the $\mathrm{N}$ removal rates. The ratio of DNRA to denitrification and the rates of $\mathrm{N}_{\text {org }}$ input and ammonification are the most sensitive sediment processes for $\mathrm{N}$ removal in this study. Our results show that DNRA needs to be included in diagenetic models of the sediment N-cycle. Additionally, a better understanding of the controls on the interaction between DNRA and denitrification is needed before such models can be used as predictive tools. 
Acknowledgements We gratefully acknowledge the crew of the RV Navicula and members of the Utrecht University geochemistry research group for their help in the field. We thank Debby Los and Dineke van de Meent for analysis, and Parisa Jourabchi for the use of the reaction transport model. Philippe Van Cappellen, Gerard van den Berg, and Gertjan Zwolsman are acknowledged for their contributions to this project. The Netherlands Institute for Inland Water Management and Waste Water Treatment (RIZA) supported the fieldwork and RWC (contract no. RI-3494). AML was supported by a VENI fellowship of the Netherlands Organization for Scientific Research (NWO). CPS was supported by a fellowship of the Royal Netherlands Academy of Arts and Sciences (KNAW).

\section{References}

Aguilera, D. R., P. Jourabchi, C. Spiteri \& P. Regnier, 2005. A knowledge-based reactive transport approach for the simulation of biogeochemical dynamics in earth systems. Geochemistry, Geophysics, Geosystems 6: Q07012.

An, S. M. \& W. S. Gardner, 2002. Dissimilatory nitrate reduction to ammonium (DNRA) as a nitrogen link, versus denitrification as a sink in a shallow estuary (Laguna Madre/Baffin Bay, Texas). Marine EcologyProgress Series 237: 41-50.

Anonymous, 1998. MER beheer Haringvlietsluizen report (Environmental Impact Report- Haringvliet dam management). Rijkswaterstaat directie Zuid-Holland, APV 98.186 (in Dutch).

Berner, R. A., 1980. Early diagenesis. A theoretical approach. Princeton University Press, Princeton NJ.

Boudreau, B. P., 1984. On the equivalence of nonlocal and radial-diffusion model for porewater irrigation. Journal of Marine Research 42: 731-735.

Canavan, R. W., C. P. Slomp, P. Jourabchi, P. Van Cappellen, A. M. Laverman \& G. A. van den Berg, 2006. Organic matter mineralization in sediment of a coastal freshwater lake and response to salinization. Geochimica et Cosmochimica Acta 70: 2836-2855.

Cloern, J. E., 2001. Our evolving conceptual model of the coastal eutrophication problem. Marine Ecology-Progress Series 210: 223-253.

de Jonge, V. N., M. Elliott \& E. Orive, 2002. Causes, historical development, effects and future challenges of a common environmental problem: eutrophication. Hydrobiologia 475: 1-19.

Gardner, W. S., S. P. Seitzinger \& J. M. Malczyk, 1991. The effects of sea salts on the forms of nitrogen released from estuarine and freshwater sediments: Does ion pairing affect ammonium flux. Estuaries 14: 157-166.

Gardner, W. S., L. Y. Yang, J. B. Cotner, T. H. Johengen \& P. J. Lavrentyev, 2001. Nitrogen dynamics in sandy freshwater sediments (Saginaw Bay, Lake Huron). Journal of Great Lakes Research 27: 84-97.
Gilbert, F., P. Souchu, M. Bianchi \& P. Bonin, 1997. Influence of shellfish farming activities on nitrification, nitrate reduction to ammonium, and denitrification at the water-sediment interface of Thau lagoon, France. Marine Ecology Progress Series 151: 143-153.

Jourabchi, P., P. Van Cappellen \& P. Regnier, 2005. Quantitative interpretation of $\mathrm{pH}$ distributions in aquatic sediments: A reaction-transport modeling approach. American Journal of Science 305: 919-956.

Kelly-Gerreyn, B. A., M. Trimmer \& D. J. Hydes, 2001. A diagenetic model discriminating denitrification and dissimilatory nitrate reduction to ammonium in a temperate estuarine sediment. Marine Ecology-Progress Series 220: 33-46.

Laverman, A. M., P. Van Cappellen, D. van RotterdamLos, C. Pallud \& J. Abell, 2006. Potential rates and pathways of microbial nitrate reduction in coastal sediments. FEMS Microbiology Ecology 58: 178-192.

Mackin, J. E. \& R. C. Aller, 1984. Ammonia adsorption in marine sediments. Limnology and Oceanography 29: $250-257$.

Magalhães, C. M., W. J. Wiebe, S. B. Joye \& A. A. Bordalo, 2005. Inorganic nitrogen dynamics in intertidal rocky biofilms and sediments of the Douro River Estuary (Portugal). Estuaries 28: 592-607.

Megonigal, J. P., M. E. Hines \& P. T. Visscher, 2003. Anaerobic metabolism: Linkages to trace gases and aerobic processes. In Schlesinger, W. H. (ed.), Biogeochemistry. 8, Treatise on Geochemistry. H. D. Hollands and K. K. Turekian (eds.). Elsevier-Pergamon, Oxford: 317-424.

Ogilvie, B., D. B. Nedwell, R. M. Harrison, A. Robinson \& A. Sage, 1997. High nitrate, muddy estuaries as nitrogen sinks: The nitrogen budget of the River Colne estuary (United Kingdom). Marine Ecology-Progress Series 150: 217-228.

Revsbech, N. P., J. P. Jacobsen \& L. P. Nielsen, 2005. Nitrogen transformations in microenvironments of river beds and riparian zones. Ecological Engineering 24: 447-455.

Rysgaard, S., P. Thastum, T. Dalsgaard, P. B. Christensen \& N. P. Sloth, 1999. Effects of Salinity on $\mathrm{NH}_{4}^{+}$ Adsorption Capacity, Nitrification, and Denitrification in Danish Estuarine Sediments. Estuaries 22(1): 21-30.

Saunders, D. L. \& J. Kalff, 2001. Nitrogen retention in wetlands, lakes and rivers. Hydrobiologia 443: 205-212.

Seitzinger, S. P., 1988. Denitrification in freshwater and coastal marine ecosystems: Ecological and geochemical significance. Limnology and Oceanography 33: 702-724.

Seitzinger, S. P., W. S. Gardner \& A. K. Spratt, 1991. The effect of salinity on ammonium sorption in aquatic sediments: Implications for benthic nutrient recycling. Estuaries 14: 167-174.

Smit, H., R. Smits, G. van der Velde \& H. Coops, 1997. Ecosystem responses in the Rhine-Meuse delta during two decades after enclosure and steps toward estuary restoration. Estuaries 20: 504-520.

Sørensen, J., 1987. Nitrate reduction in marine sediment: pathways and interactions with iron and sulfur cycling. Geomicrobiology Journal 5: 401-421. 
Stief, P., A. Schramm, D. Altmann \& D. de Beer, 2003. Temporal variation of nitrification rates in experimental freshwater sediments enriched with ammonia or nitrite. FEMS Microbiology Ecology 46: 63-71.

Van Cappellen, P. \& Y. F. Wang, 1996. Cycling of iron and manganese in surface sediments: A general theory for the coupled transport and reaction of carbon, oxygen, nitrogen, sulfur, iron, and manganese. American Journal of Science 296: 197-243.
Westrich, J. T. \& R. A. Berner, 1984. The role of sedimentary organic matter in bacterial sulfate reduction: the G-model tested. Limnology and Oceanography 29: 236-249.

Windolf, J., E. Jeppesen, J. P. Jensen \& P. Kristensen, 1996. Modelling of seasonal variation in nitrogen retention and in-lake concentration: A four-year mass balance study in 16 shallow Danish lakes. Biogeochemistry 33: 25-44. 